\section{Phytotoxicity in soybean seeds treated with phytosanitary products at different application times}

\author{
Everson Reis Carvalho ${ }^{1^{*}}\left(\mathbb{D}\right.$, Debora Kelli Rocha ${ }^{1}$, Dayliane Bernardes de \\ Andrade $^{1}\left(\mathbb{D}\right.$, Raquel Maria de Oliveira Pires ${ }^{1}$ D , Amanda Carvalho Penido ${ }^{1}$, \\ Leandro Vilela Reis ${ }^{1}$ iD
}

ABSTRACT: Due to increased use of treated seeds, studies are necessary in relation to the effects of the treatments and their possible consequences on seed quality. The aim of this study was to evaluate phytotoxicity according to when phytosanitary products are applied on soybean seeds and their effect on seed physiological quality and field performance. A completely randomized experimental design was used in a $9 \times 2$ factorial arrangement involving 9 seed treatments (fungicides and insecticides) and two application times (60 days before sowing and at the time of sowing in the field). Moisture content was determined and tests were performed to ascertain physiological quality (germination and germination under water restriction). Root and hypocotyl length, seedling length, and vigor and uniformity indices were evaluated with the assistance of Vigor-S ${ }^{\circledR}$. In the field, the following determinations were made: plant height at 30 and 60 days after emergence, first pod height, number of pods per plant, number of seeds per pod, and yield. Early seed treatment in the soybean crop can affect initial development of the plants, but it does not affect yield. The phytotoxicity caused by the soybean seed treatment was observed in the root length characteristic.

Index terms: fungicides, insecticides, physiological quality, seed treatment, Vigor-S ${ }^{\circledR}$.

\section{Fitotoxicidade em sementes de soja tratadas com produtos} fitossanitários em diferentes momentos de aplicação

RESUMO: Devido ao crescente uso de sementes tratadas, faz-se necessário estudos em relação aos efeitos do tratamento e seus possíveis reflexos na qualidade de sementes. O objetivo foi avaliar a fitotoxicidade em função da época de aplicação de produtos fitossanitários em sementes de soja e seu efeito sobre a qualidade fisiológica e desempenho em campo. Utilizou-se o delineamento inteiramente casualizado, fatorial 9x2, envolvendo 9 tratamentos de sementes (fungicidas e inseticidas) em dois momentos de aplicação (60 dias antes e no momento da semeadura no campo). Realizou-se a determinação do teor de água e de testes para averiguar a qualidade fisiológica (germinação e germinação por restrição hídrica) e com o auxílio do Vigor- ${ }^{\circledR}$ avaliou-se comprimento da raiz e do hipocótilo, comprimento de plântulas, índices de vigor e de uniformidade. Em campo realizou-se altura de plantas aos 30 e aos 60 dias após a emergência, altura de inserção da primeira vagem, número de vagens por planta, número de sementes por vagem e produtividade. A antecipação do tratamento de sementes na cultura da soja, pode afetar o desenvolvimento inicial das plantas, mas não prejudica a produtividade. A fitotoxicidade causada pelo tratamento das sementes de soja é evidente pela característica comprimento das raízes.

Termos para indexação: fungicidas, inseticidas, qualidade fisiológica, tratamento de sementes, Vigor-S ${ }^{\circledR}$.
Journal of Seed Science, v.42, e202042036, 2020

http://dx.doi.org/10.1590/ 2317-1545v42237847

\author{
*Corresponding author \\ E-mail: eversoncarvalho@ufla.br
}

Received: 5/10/2020. Accepted: 6/10/2020.

\footnotetext{
${ }^{1}$ Universidade Federal de Lavras (UFLA), Escola de Ciências Agrárias de Lavras (ESAL), Departamento de Agricultura, Setor de Sementes, 37200-900 - Lavras, MG, Brasil.
} 


\section{INTRODUCTION}

In economic terms, soybean is one of the most important crops in Brazil. An area of 36.94 million hectares were dedicated to the crop in the 2019/20 crop year (CONAB, 2020), contributing in a significant manner to Brazilian exports (Santos et al., 2018). Diverse management techniques have been adopted to increase soybean yield; chemical seed treatment is one of the most prominent (Brzezinski et al., 2015).

This explains the search for technologies that improve soybean seed performance in the field. In recent years, seed technology has advanced progressively, and physiological potential as well, driven by technological advances through research (Nunes et al., 2014). Physiological potential is one of the attributes that composes seed quality (Marcos-Filho, 2015), and this should be monitored in internal quality control of seed lots for the commercial seed trade; physiological potential is associated with germination and vigor (Wendt et al., 2017).

Industrial Seed Treatment (IST) has gained ground in the soybean seed market; various companies already make use of this technology (Ferreira et al., 2016). In this process, technical and logistical matters determine that seeds be treated before being packed and then stored up to the time of sowing (Brzezinski et al., 2015; Santos et al., 2018). However, storage of treated seeds can have some unintended consequences, such as possible detrimental effects from the chemical products on the seeds, as reported for some molecules by Dan et al. (2010), Piccinin et al. (2013), Ferreira et al. (2016) and Santos et al. (2018).

Depending on how much time in advance the seeds are treated, seed treatment before packing can be harmful. Yet, because of the logistical requirements of sowing, especially in regard to IST, it may be necessary. Therefore, monitoring the time that the soybean seed can remain with treatment without hurting its physiological quality (seed safety) is of great importance.

Early seed treatment can affect results of the seed lot in the field, as found by Brzezinski et al. (2015), in which seed treatment 240 days before sowing hurt plant establishment and soybean yield compared to treatment just shortly before sowing.

Early industrial seed treatment may have some limiting factors, such as possible effects that the active ingredients of the chemical products have on the seeds and, subsequently, on field performance. Ferreira et al. (2016) found that the mixtures of some insecticides hurt the physiological quality of treated soybean seeds after two months of storage. According to Rocha et al. (2020), treatments of soybean seeds with insecticide molecules affect the germination and evaluation of the seedlings, and have greater phytotoxicity than fungicide molecules.

In light of the above, the aim of this study was to evaluate the phytotoxicity of seed treatments according to when the phytosanitary products were applied on soybean seeds and their effect on physiological quality and performance in the field.

\section{MATERIAL AND METHODS}

Soybean seeds from a single seed lot of the cultivar (Syn 1366C IPRO) were divided into two kilogram portions, which were treated with the phytosanitary products. The seed treatments involved eight phytosanitary products, including fungicides and nematicides (Table 1), and the control treatment, with water alone (Table 1). The maximum volume of the mixture used was $600 \mathrm{~mL} .100 \mathrm{~kg}^{-1}$ of seed (product + water), consisting of the recommended dose of the product and added water.

Five (5) kilogram capacity plastic bags were used for the seed treatment. The mixtures with the seed treatment products were applied on the seeds, which were then shaken in the plastic bags until complete homogenization. After the treatment, the seeds were placed in the shade at a temperature of approximately $25{ }^{\circ} \mathrm{C}$ for 20 minutes for the product to dry on the surface of the seeds. The seed treatments were performed alternatively at a considerable time in advance of sowing (early treatment) or at the time of sowing in the field. Early treatment was at 60 days before sowing and, after treatment, the seeds were placed in multilayered kraft paper bags, which remained in a climate-controlled environment at $20{ }^{\circ} \mathrm{C}$ and $60 \%$ relative humidity. The seeds that received the treatments at the time of sowing were 
Table 1. Active ingredients, commercial products, classification, and application rates for treatment of soybean seeds.

\begin{tabular}{|c|c|c|c|c|}
\hline Active ingredient (a.i) & Commercial name & Classification $^{1}$ & Commercial product rate ${ }^{2}$ & Added water ${ }^{3}$ \\
\hline Imidacloprid + Thiodicarb & Cropstar $^{\circledR}$ & $1+1$ & 600 & - \\
\hline Thiamethoxam & Cruiser $350 \mathrm{FS}^{\circledR}$ & I & 300 & 300 \\
\hline Acetamiprid & Pirâmide ${ }^{\circledR}$ & 1 & 200 & 400 \\
\hline Cyantraniliprole & Fortenza $600 \mathrm{FS}^{\circledR}$ & 1 & 200 & 400 \\
\hline Carbendazim + Thiram & Derosal Plus ${ }^{\circledR}$ & $F+F$ & 200 & 400 \\
\hline Fludioxonil + Metalaxyl-M & Maxim XL ${ }^{\circledR}$ & $F+F$ & 100 & 500 \\
\hline Thiophanate-methyl +Fluazinam & Certeza $^{\circledR}$ & $F+F$ & 200 & 400 \\
\hline Fipronil + Pyraclostrobin + Methyl thiophanate & Standak Top ${ }^{\circledR}$ & $I+F+F$ & 200 & 400 \\
\hline Control & - & - & - & 600 \\
\hline
\end{tabular}

${ }^{1} \mathrm{I}$ : insecticide; F: fungicide; ${ }^{2}$ Commercial product application rate: $\mathrm{mL} .100 \mathrm{~kg}^{-1}$ of seeds; ${ }^{3} \mathrm{Added}$ water: $\mathrm{mL} .100 \mathrm{~kg}{ }^{-1}$ of seeds; Volume of mixture: $600 \mathrm{~mL} .100 \mathrm{~kg}^{-1}$ of seeds.

stored during these 60 days in the same environment as the seeds treated in advance. At the time of sowing, the seeds were treated with the same phytosanitary products (Table 1), following the same procedures as for the early treatment.

Moisture content was determined and physiological analyses were performed on the seeds that remained after the seeds were sown in the field, soon after the sowing operation. These evaluations were performed in a laboratory certified by the Brazilian Ministry of Agriculture (Ministério da Agricultura e Abastecimento - MAPA) in Uberlândia, MG, Brazil, with the following tests:

Determination of moisture content: performed in a laboratory oven at $105 \pm 3^{\circ} \mathrm{C}$ for 24 hours, according to instructions of the Rules for Seed Testing (Brasil, 2009). Two 10-gram replicates of seeds were used for each block. The results were expressed in mean percentage based on wet weight. Germination: in a paper towel substrate (Germitest - germination testing paper) in the form of a roll, moistened with water in the amount of 2.5 times the dry weight of the paper. Four (4) replicates of 50 seeds were sown for each block, which were placed in a seed germinator at $25^{\circ} \mathrm{C}$, without photoperiod. Results were expressed in percentages of normal seedlings (Brasil, 2009).

Germination under water restriction $(G H)$ : performed according to the method described above for the germination test; however, an aqueous solution containing mannitol (P.A C6H14O6 - M.W. 182.17) was used to moisten the germination paper for artificial simulation of water restriction and to obtain osmotic potential of $-0.25 \mathrm{MPa}$ (Rocha et al., 2020). Four (4) replicates of 50 seeds were used for each block. Evaluation was carried out according to the Rules for Seed Testing (Brasil, 2009), and results were expressed in percentages of normal seedlings.

For computerized analysis of seedling images (Vigor- $\mathrm{S}^{\circledR}$ ), four (4) replicates of 20 seeds were used per block, distributed in two rows on the upper third of two sheets of paper towel (Germitest) and covered with a third sheet. All the sheets were first moistened with water in the amount of 2.5 times the dry weight of the paper. After covering the seeds with the third sheet of moistened paper, rolls were made, which were placed in a seed germinator at $25^{\circ} \mathrm{C}$ for three days. After that period, for later evaluation on the Vigor $\mathrm{S}^{\circledR}$ computational program, the seedlings were digitalized through a HP Scanjet 200 scanner, set up in an inverted position within an aluminum box $(60 \times 50 \times 12 \mathrm{~cm})$, adjusting resolution to $300 \mathrm{dpi}$.

Numerical values were generated through the Vigor $S^{\circledR}$ software in reference to the vigor index, seedling growth, and uniformity of development (values on an absolute scale from 0 to 1000 , directly proportional to vigor), as well as values of mean length of the hypocotyl and roots of seedlings, in centimeters. The equations for calculation of the vigor and uniformity of growth indices were determined according to those established by Sako et al. (2001) for SVIS ${ }^{\circledR}$. However, to calculate the uniformity index using Vigor-S, an adaptation of the Christiansen uniformity coefficient was used (Christiansen, 1942). 
After the procedures of treatment on the day of sowing and early treatment, part of the seeds was used for sowing in the field and the rest were directed to the physiological analyses and image analyses conducted in the laboratory.

Soil in the experimental area is classified as a Latossolo Vermelho distrófico of clayey texture. The area chosen for setting up the experiment had homogeneity of physical and chemical characteristics and of previous crops, in addition to flat topography. The experiment was conducted in an area at $18^{\circ} 43^{\prime} 29^{\prime \prime} \mathrm{S}, 47^{\circ} 29^{\prime} 55^{\prime \prime} \mathrm{W}$, at 870 masl. The climate is Aw according to the Köppen classification. Data regarding rainfall, temperature, and relative humidity during the period of carrying out the experiment are shown in Figure 1.

After soil sampling (0-20 cm depth), fertilizer was applied in the furrow at the time of planting, following the specifications for the crop (Ribeiro et al.,1999), with single superphosphate and potassium chloride sources. Planting furrows, at a $0.50 \mathrm{~m}$ spacing, were opened by mechanically drawn equipment in a no-till system, and Bradyrhizobium was inoculated in the planting furrow. Seeds were sown manually and seedlings thinned at 15 days after seedling emergence, maintaining 13 plants per meter, thus standardizing the stand at 260,000 plants per hectare for all the treatments.

The experimental plots consisted of four 5-meter length rows. The two center rows were used for data collection, with elimination of the $0.50 \mathrm{~m}$ at their extremities that constituted a border area. Weeds, pests, and diseases were managed in a uniform manner throughout the crop cycle in accordance with their occurrence.

The agronomic evaluations made were plant height at 30 and at 60 days after emergence ( 30 and $60 \mathrm{DAE}$ ), first pod height, number of pods per plant, and number of seeds per pod through sampling 10 plants at random from the area used for data collection. Grain yield $\left(\mathrm{kg} \cdot \mathrm{ha}^{-1}\right)$ was estimated, adjusted to $13 \%$ moisture content.

The study was conducted in a randomized block experimental design (RBD), with 3 blocks. A $9 \times 2$ factorial arrangement was adopted, involving 9 seed treatments and 2 alternate application times, early application (60 days before sowing) or at the time of sowing in the field.

Analysis of variance was carried out on the data with the assistance of the Sisvar ${ }^{\circledR}$ software (Ferreira, 2014) at $5 \%$ probability by the $F$ test $(p<0.05)$. In the event of significant effect, the Scott-Knott test was used at $5 \%$ probability $(p<0.05)$.

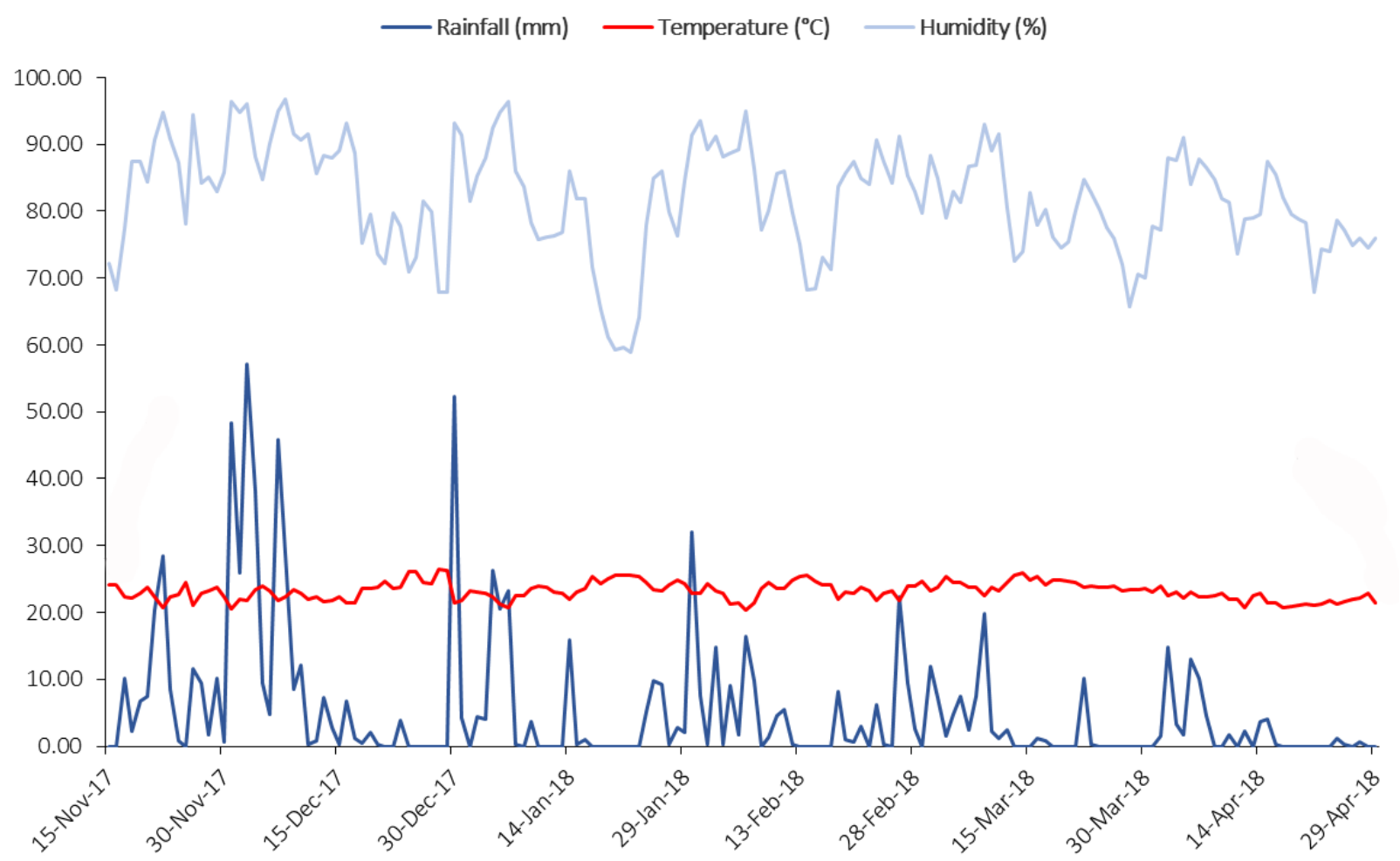

Figure 1. Data of rainfall $(\mathrm{mm})$, temperature $\left({ }^{\circ} \mathrm{C}\right)$, and relative humidity $(\%)$ over the period of carrying out the experiment. 


\section{RESULTS AND DISCUSSION}

The seed lots exhibited uniformity regarding moisture contents, with values near $9 \%$; the difference between the lowest and highest values was only $0.5 \%$, ensuring reliability of the results of evaluations of seed physiological potential. The uniformity of moisture content among seed lots is of utmost importance in obtaining consistent results, because differences greater than 2 to 3 percentage points can interfere in the results of the physiological quality test (Marcos-Filho, 1999).

The time of seed treatment did not affect germination in paper as well as germination with water restriction. These tests alone may not be sufficient to detect possible harmful effects of early treatment, due to the methods and principles used for them.

Nevertheless, regardless of the time of application, the germination test showed that seeds treated with the insecticides Cropstar $^{\circledR}$, Cruiser $^{\circledR}$, and Pirâmide ${ }^{\circledR}$ had a lower percentage of normal seedlings than the seeds treated with the other products, which confirms that some insecticide molecules can show toxicity in physiological analyses, especially in a paper substrate (Brzezinski et al., 2015; Ferreira et al., 2016; Santos et al., 2018). Rocha et al. (2020) observed that the treatments of soybean seeds with insecticide molecules affect germination and seedling evaluation, with greater phytotoxicity in relation to fungicide molecules, especially in analysis methods with abundant and readily available water.

In spite of the phytotoxicity observed, all the percentages of germination were above the minimum required for commercialization of soybean seeds, which currently is $80 \%$ (Brasil, 2013). The lowest germination of the seed lots evaluated was through water restriction, at $96 \%$. However, due to the low coefficient of variation, small differences were indicated as significant; the insecticides Cruiser $^{\circledR}$ and Pirâmide ${ }^{\circledR}$ and the fungicides Derosal Plus ${ }^{\circledR}$ and Certeza ${ }^{\circledR}$ had the lowest values (Table 2).

In relation to the variables resulting from computerized analysis of seeds and seedlings, seedling length was shorter in seeds treated with the insecticides $\operatorname{Cropstar}^{\circledR}, \mathrm{Cruiser}^{\circledR}$, Pirâmide ${ }^{\circledR}$, and Fortenza ${ }^{\circledR}$ and with the fungicides Derosal $\mathrm{Plus}^{\circ}$ and Maxim $\mathrm{XL}^{\circ}$ (Table 2). Some seed treatment molecules may not only lead to seedling abnormalities but may also reduce seedling growth, even though they are considered normal seedlings. This difference in length can be detected through image analysis; a difference of $28 \%$ was observed between the control treatment and the shortest seedling length in seeds treated with Pirâmide ${ }^{\circ}$. For uniformity analysis, values greater than 600 were found in all

Table 2. Percentages of germination (Germ.), germination under water restriction (GWR), and parameters obtained by means of image analysis (Vigor $S^{\circledR}$ ): seedling length (Seedling $L$ ) and uniformity (Unif.) in accordance with seed treatments (ST) with phytosanitary products.

\begin{tabular}{|c|c|c|c|c|}
\hline $\mathrm{ST}^{*}$ & Germ. (\%) & GWR (\%) & Seedling L $(\mathrm{cm})$ & Unif. (index) \\
\hline Cropstar $^{\circledR}$ (I) & $95 \mathrm{~b}$ & $99 a$ & $5.6 \mathrm{~b}$ & $747.5 \mathrm{a}$ \\
\hline Cruiser $^{\circledR}(\mathrm{I})$ & $95 \mathrm{~b}$ & $96 b$ & $5.6 \mathrm{~b}$ & $720.3 \mathrm{a}$ \\
\hline Pirâmide ${ }^{\circledR}$ (I) & $96 \mathrm{~b}$ & $96 \mathrm{~b}$ & $5.4 \mathrm{~b}$ & $639.8 \mathrm{~b}$ \\
\hline Fortenza ${ }^{\circledR}(\mathrm{I})$ & $97 a$ & $98 \mathrm{a}$ & $6.2 \mathrm{~b}$ & $747.0 \mathrm{a}$ \\
\hline Derosal Plus $^{\circledast}(\mathrm{F})$ & $98 a$ & $96 \mathrm{~b}$ & $6.1 b$ & $690.5 \mathrm{~b}$ \\
\hline $\operatorname{Maxim} X^{\circledR}(F)$ & $98 \mathrm{a}$ & $98 \mathrm{a}$ & $6.1 b$ & $681.4 \mathrm{~b}$ \\
\hline Certeza $^{\circledR}(\mathrm{F})$ & $98 \mathrm{a}$ & $96 b$ & $7.0 \mathrm{a}$ & 749.6 a \\
\hline Standak Top ${ }^{\circledR}$ (IF) & $98 \mathrm{a}$ & $98 \mathrm{a}$ & $7.1 \mathrm{a}$ & $734.0 \mathrm{a}$ \\
\hline Control & $99 \mathrm{a}$ & $97 a$ & $7.6 \mathrm{a}$ & $756.1 \mathrm{a}$ \\
\hline CV (\%) & 2.14 & 2.18 & 20.92 & 7.44 \\
\hline
\end{tabular}

*I: insecticide, F: fungicide. CV: coefficient of variation. Mean values followed by the same letter in the column do not differ from each other by the Scott-Knott test at $5 \%$ probability. Seedling $L$ and Unif. obtained by Vigor $S^{\circledR}$ 
the lots; however, seedlings coming from seeds treated with the products Pirâmide ${ }^{\circledR}$, Derosal Plus ${ }^{\circledR}$ and $\mathrm{Maxim}^{\mathrm{XL}}{ }^{\circledR}$ exhibited lower uniformity (Table 2).

The total seedling length, hypocotyl length and seedling uniformity were lower when coming from seeds that received early treatment at 60 days prior to sowing (Table 3); this difference was not found through the conventional physiological tests performed in this study. Evaluation of these characteristics through image analysis was effective and sensitive for detection of initial harmful processes in soybean seeds before consequent abnormalities in seedlings.

In the same manner, Silva et al. (2012) concluded that seedling length and the vigor and growth indices obtained in analysis through the Seed Vigor Imaging System (SVIS ${ }^{\circledR}$ ) were effective in classification of eggplant seed lots. LeãoAraújo et al. (2017) indicated that the indices generated uisng SVIS ${ }^{\circledR}$, including uniformity in seedling development, were able to effectively separate crambe seed lots.

In analysis of root length, when there was a difference between the treatment periods, the seeds that received the treatment at the time of sowing generated seedlings that had higher values than the seedlings from seeds that received early treatment. This difference occurred for the insecticides Cruiser ${ }^{\circledR}$, Pirâmide ${ }^{\circledR}$, and Fortenza ${ }^{\circledR}$ and for the fungicide Maxim $\mathrm{XL}^{\circledR}$, as well as for the control treatment with water (Table 4).

In early treatment, the insecticide products Cruiser $^{\circledR}$ and Pirâmide ${ }^{\circledR}$ were most harmful to development of seedling roots. Even when performed at the time of sowing, all the chemical treatments resulted in a decrease in root

Table 3. Total length of the seedling (Seedling L), of the hypocotyl (Hyp.), and uniformity (Unif.) obtained by image analysis (Vigor-S $S^{\circ}$ in accordance with the time of seed treatment (Time ST) with phytosanitary products.

\begin{tabular}{cccc}
\hline Time ST* & Seedling L $(\mathrm{cm})$ & Hyp. $(\mathrm{cm})$ & Unif. (index) \\
\hline Early & $5.0 \mathrm{~b}$ & $1.63 \mathrm{~b}$ & $693.7 \mathrm{~b}$ \\
At sowing & $7.0 \mathrm{a}$ & $2.00 \mathrm{a}$ & $743.3 \mathrm{a}$ \\
\hline${ }^{* *} \mathrm{CV}(\%)$ & 20.92 & 24.14 & 7.44 \\
\hline
\end{tabular}

*Mean values followed by the same letter in the column do not differ from each other by the $\mathrm{F}$ test at $5 \%$ probability. ${ }^{* *} \mathrm{CV}$ : coefficient of variation. Early = treatment performed 60 days before sowing; At sowing = treatment performed moments before sowing.

Table 4. Root length, in centimeters, in accordance with the times of application and the treatments of seeds with phytosanitary products (ST), obtained through image analysis (Vigor- $\mathrm{S}^{\circ}$ ).

\begin{tabular}{|c|c|c|}
\hline \multirow{2}{*}{$\mathrm{ST}^{*}$} & \multicolumn{2}{|c|}{ Time of seed treatment } \\
\hline & Early & At sowing \\
\hline Cropstar $^{\circledast}$ (I) & $4.66 \mathrm{Aa}$ & $4.66 \mathrm{Ac}$ \\
\hline Cruiser $^{\circledast}(\mathrm{I})$ & $3.10 \mathrm{Bc}$ & $4.71 \mathrm{Ac}$ \\
\hline Pirâmide ${ }^{\circledR}$ (I) & $2.10 \mathrm{Bd}$ & $3.46 \mathrm{Ad}$ \\
\hline Fortenza ${ }^{\circledR}(\mathrm{I})$ & $3.90 \mathrm{Bb}$ & $5.08 \mathrm{Ab}$ \\
\hline Derosal Plus ${ }^{\circledast}(F)$ & $4.34 \mathrm{Aa}$ & $4.50 \mathrm{Ac}$ \\
\hline $\operatorname{Maxim} X I^{\circledast}(F)$ & $3.80 \mathrm{Bb}$ & $4.73 \mathrm{Ac}$ \\
\hline Certeza $^{\circledR}(\mathrm{F})$ & $4.80 \mathrm{Aa}$ & $5.26 \mathrm{Ab}$ \\
\hline Standak Top ${ }^{\circledR}$ (IF) & $4.48 \mathrm{Aa}$ & $5.88 \mathrm{Aa}$ \\
\hline Control & $5.15 \mathrm{Ba}$ & $6.15 \mathrm{Aa}$ \\
\hline CV (\%) & & \\
\hline
\end{tabular}

*I: insecticide, F: fungicide. ${ }^{* *}$ Mean values followed by the same lowercase letters in the column and uppercase letters in the row do not differ from each other by the Scott-Knott test at $5 \%$ probability. Early = treatment performed 60 days before sowing; At sowing = treatment performed moments before sowing. 
development, except for the treatment Standak Top ${ }^{\circledR}$, which did not differ from the control. For both treatment periods, the insecticide Pirâmide ${ }^{\circledR}$ led to less root development, with inhibition of $59 \%$ in early treatment and $44 \%$ in treatment at sowing in relation to the control, indicating high sensitivity of this variable for analysis of this type of phytotoxicity.

Dan et al. (2010) also observed a negative effect on root growth of soybean seedlings when seeds were treated with different insecticides, especially when the treated seeds were stored ( 240 days). In the same way, Ludwig et al. (2011) reported a reduction of $26 \%$ in dry matter of seedlings coming from soybean seeds treated with fungicides and insecticides and then stored for up to 120 days; the seeds showed a reduction in the capacity of translocating reserves to the embryo. Pereira et al. (2018) studied the effect of industrial treatment on the physiological potential of soybean seeds during storage (up to 120 days) and concluded that the germination and vigor of the soybean seeds decline over the storage period.

However, it should be emphasized that in spite of the reduction in development of the seedlings in function of the anticipated treatment ( 60 days), there were no reductions to levels below the standard for the commercial seed trade. Zambon (2013) and Strieder et al. (2014) recommended performing the industrial seed treatment process at most 60 days before the beginning of sowing so as to minimize possible toxic effects on plants from the mixtures applied on the seeds.

Evaluation of root development through measuring length with the image analysis method that was used was also effective for evaluation of the phytotoxicity of the phytosanitary products to the soybean seeds and seedlings.

Vanzolini et al. (2007) sought to correlate the data on seedling and root length with the data on seedling emergence in the field and concluded that only the root length measurement obtained correlation that allowed differentiation of the soybean seed lots. Like Vanzolini et al. (2007), other authors reported root length measurement as sensitive for differentiation of soybean seed lots (Krzyzanowski, 1991; Nakagawa, 1999; Vanzolini and Carvalho, 2002).

In general, the seed lots that received treatment at the time of sowing had greater vigor (Table 5). For the treatments with Cropstar $^{\circledR}$, Derosal Plus ${ }^{\circledR}$ and Certeza ${ }^{\circledR}$, there was no difference of the vigor index according to the time of treatment. For early treatment, the insecticides Pirâmide ${ }^{\circledR}$ and Cruiser $^{\circledR}$ led to lower vigor indices. For treatment at the time of sowing, once more the insecticide Pirâmide ${ }^{\circ}$ led to a lower seedling vigor index. For treatment at that time, the control, Standak Top ${ }^{\circledR}$, Certeza $^{\circledR}$, Fortenza ${ }^{\circledR}$ and Cruiser $^{\circledR}$ led to higher vigor indices.

The preliminary standard for vigor established by the Ohio Seed Improvement Association (which considers high

Table 5. Vigor indices obtained by image analysis (Vigor-S ${ }^{\circledR}$ ) in accordance with the times of application and treatments of seeds with phytosanitary products.

\begin{tabular}{ccc}
\hline Product* $^{*}$ & \multicolumn{2}{c}{ Time of seed treatment } \\
\cline { 2 - 3 } & Early & At sowing \\
\hline Cropstar $^{\circledast}(\mathrm{I})$ & $590.2 \mathrm{Aa}$ & $544.9 \mathrm{Ac}$ \\
Cruiser $^{\circledR}(\mathrm{I})$ & $440.3 \mathrm{Bc}$ & $600.5 \mathrm{Ab}$ \\
Pirâmide $^{\circledast}(\mathrm{I})$ & $351.2 \mathrm{Bd}$ & $468.7 \mathrm{Ad}$ \\
Fortenza $^{\circledR}(\mathrm{I})$ & $515.6 \mathrm{Bb}$ & $629.7 \mathrm{Ab}$ \\
Derosal Plus $^{\circledast}(\mathrm{F})$ & $539.0 \mathrm{Ab}$ & $560.8 \mathrm{Ac}$ \\
Maxim XL $^{\circledR}(\mathrm{F})$ & $491.9 \mathrm{Bb}$ & $581.1 \mathrm{Ac}$ \\
Certeza $^{\circledast}(\mathrm{F})$ & $591.9 \mathrm{Aa}$ & $621.6 \mathrm{Ab}$ \\
Standak Top $^{\circledast}(\mathrm{IF})$ & $567.0 \mathrm{Ba}$ & $675.6 \mathrm{Aa}$ \\
Control & $609.9 \mathrm{Ba}$ & $716.4 \mathrm{Aa}$ \\
\hline
\end{tabular}

CV (\%)

8.86

*I: insecticide, F: fungicide. CV: coefficient of variation. Mean values followed by the same lowercase letters in the column and uppercase letters in the row do not differ from each other by the Scott-Knott test at $5 \%$ probability.

Early = treatment performed 60 days before sowing; At sowing = treatment performed moments before sowing. 
vigor $>500$, medium vigor from $200-500$, and low vigor $<200$ ) shows that most of the phytosanitary treatments used at the time of sowing obtained high vigor, except for the Pirâmide ${ }^{\circledR}$ treatment. In early treatment, medium vigor is observed for the treatments with Cruiser ${ }^{\circledR}$, Pirâmide ${ }^{\circledR}$ and Maxim XL ${ }^{\circledR}$. For the Pirâmide ${ }^{\circledR}$ treatment, a reduction of $25 \%$ was observed in the vigor index with early treatment.

In a way similar to that observed for the vigor index, the seed lots that received the treatment at the time of sowing had a greater growth index, except for those that received Cropstar ${ }^{\circledR}$, Derosal Plus ${ }^{\circledR}$ and Certeza ${ }^{\circledR}$, in which the time of the treatment had no effect (Table 6). In the early treatment, there was a lower seedling growth index in seeds treated with Pirâmide ${ }^{\circledR}$ and Cruiser $^{\circledR}$. However, for the treatment at the time of sowing, the insecticides Pirâmide and Cropstar ${ }^{\circ}$ were most detrimental to the growth index.

In general, the vigor and growth indices exhibited similar discrimination of seed treatments. According to Nakagawa (1999), the tests of the length of seedlings or of their parts have been considered effective for detecting differences in the physiological potential of seeds of various species. At the same time, in addition to this sensitivity, their results may show a close relationship with seedling emergence in the field (Krzyzanowski, 1991; Vanzolini et al., 2007; Marcos-Filho et al., 2009). Thus, the parameters calculated in accordance with the lengths of seedlings and their parts, obtained through the method described in this study, can be useful for detecting small variations among seed lots and levels of phytotoxicity and deterioration.

The characteristics evaluated with the Vigor $S^{\circledR}$ software show that the system can be adopted as a complementary quality control test in seed production companies. In a similar manner, Corrêa et al. (2019) concluded that the Seed Vigor Imaging System (SVIS ${ }^{\circledast}$ ) constitutes a technique for evaluating cotton seed vigor, as there was correlation with other tests traditionally used with the same objective. Speed in obtaining results is an important aspect of the use of computerized image analysis of seedlings (Abud et al., 2017). Medeiros et al. (2019) studied the physiological quality of common bean seeds with the Vigor-S ${ }^{\circledR}$ system and detected that the use of this image analysis technique allows evaluation of seed physiological potential, which shows the possibility of taking better advantage of the results obtained in the same evaluation.

In relation to the agronomic characteristics in the field, first pod height and the number of seeds per pod did not differ among the treatments; first pod height exhibited an overall mean of $8.62 \mathrm{~cm}$ and $\mathrm{CV}$ of $12.22 \%$, and the number of seeds per pod exhibited an overall mean of 2.34 , with a CV of $14.66 \%$. The use of the same cultivar and standardized plant stand are factors that contributed to the lack of statistical difference in these variables.

Table 6. Growth index obtained by image analysis $\left(\right.$ Vigor- $\left.\mathrm{S}^{\circledR}\right)$ in accordance with times of application and treatments of seeds with phytosanitary products.

\begin{tabular}{|c|c|c|}
\hline \multirow{2}{*}{ Product* } & \multicolumn{2}{|c|}{ Time of seed treatment } \\
\hline & Early & At sowing \\
\hline Cropstar $^{\circledast}(\mathrm{I})$ & $516.8 \mathrm{Aa}$ & $464.0 \mathrm{Ac}$ \\
\hline Cruiser $^{\circledR}(\mathrm{I})$ & $346.0 \mathrm{Bc}$ & $523.4 \mathrm{Ab}$ \\
\hline Pirâmide ${ }^{\circledR}(I)$ & $238.4 \mathrm{Bd}$ & $384.4 \mathrm{Ac}$ \\
\hline Fortenza ${ }^{\circledR}(\mathrm{I})$ & $432.1 \mathrm{Bb}$ & $563.8 \mathrm{Ab}$ \\
\hline Derosal Plus ${ }^{\circledR}(F)$ & $480.8 \mathrm{Aa}$ & $498.5 \mathrm{Ab}$ \\
\hline Maxim $X I^{\circledast}(F)$ & $422.2 \mathrm{Bb}$ & $526.6 \mathrm{Ab}$ \\
\hline Certeza $^{\circledR}(\mathrm{F})$ & $532.1 \mathrm{Aa}$ & $558.9 \mathrm{Ab}$ \\
\hline Standak Top ${ }^{\circledR}$ (IF) & $498.6 \mathrm{Ba}$ & 647.7 Aa \\
\hline Control & $567.4 \mathrm{Ba}$ & $679.2 \mathrm{Aa}$ \\
\hline
\end{tabular}

CV (\%)

11.56

*I: insecticide, F: fungicide. CV: coefficient of variation. Mean values followed by the same lowercase letters in the column and uppercase letters in the row do not differ from each other by the Scott-Knott test at $5 \%$ probability.

Early = treatment performed 60 days before sowing; At sowing = treatment performed moments before sowing. 
An effect of the phytosanitary treatments was not observed for plant height evaluated at 30 and 60 days after sowing. However, the time at which the seeds received the treatment affected the initial development of plants in the field, the heights at 30 and at 60 days. The seeds that were stored for two months after having been treated had slower initial development, resulting in shorter plant heights in relation to those that received the treatment at the time of sowing (Table 7).

In this respect, Dan et al. (2010) found reductions in emergence of seedlings coming from soybean seeds treated with insecticide and then stored. Brzezinski et al. (2015) reported that early seed treatment (240 days before sowing) hurt establishment of the crop, 1000 seed weight and grain yield in relation to treatments applied at sowing, and that the chemical treatments containing fungicides and insecticides in association favored establishment of the crop; however, they did not change the yield performance of soybean.

In evaluation of the number of pods per plant, the early treatment resulted in lower mean values than the treatment performed at the time of sowing for the insecticides Cropstar $^{\circledR}$ and Pirâmide ${ }^{\circledR}$ and the control treatment (water). For the other treatments, there was no problem with early seed treatment (Table 8).

In addition, in the early treatment, lower mean values of number of pods is observed with use of the insecticides Cropstar $^{\circledR}$ and Cruiser $^{\circledast}$, as well as in the control. The fact that the control, only water, exhibited mean values that were lower with early treatment in some variables may be related to the promotion of pathogens during storage, due to

Table 7. Plant height at 30 days and at 60 days after emergence, in centimeters, in accordance with the time of application of the treatment of soybean seeds (Time ST) with phytosanitary products.

\begin{tabular}{ccc}
\hline Time ST* & Height at 30 days & Height at 60 days \\
\hline Early & $11.0 \mathrm{~b}$ & $47.9 \mathrm{~b}$ \\
At sowing & $11.7 \mathrm{a}$ & $51.7 \mathrm{a}$ \\
\hline${ }^{*}$ CV $(\%)$ & 8.56 & 10.49 \\
\hline
\end{tabular}

*Mean values followed by the same letter in the column do not differ from each other by the $\mathrm{F}$ test at $5 \%$ probability. ${ }^{* *} \mathrm{CV}$ : coefficient of variation. Early = treatment performed at 60 days before sowing; At sowing = treatment performed moments before sowing.

Table 8. Number of pods per plant in accordance with the time of application of the treatment of soybeans seeds with phytosanitary products.

\begin{tabular}{|c|c|c|}
\hline \multirow{2}{*}{ Product* } & \multicolumn{2}{|c|}{ Time of seed treatment } \\
\hline & Early & At sowing \\
\hline Cropstar $^{\circledast}(\mathrm{I})$ & $41.93 \mathrm{Bb}$ & $65.47 \mathrm{Aa}$ \\
\hline Cruiser $^{\circledast}(\mathrm{I})$ & $41.07 \mathrm{Ab}$ & $47.63 \mathrm{Aa}$ \\
\hline Pirâmide ${ }^{\circledR}(\mathrm{I})$ & $49.43 \mathrm{Ba}$ & 63.97 Aa \\
\hline Fortenza ${ }^{\circledR}(\mathrm{I})$ & $55.77 \mathrm{Aa}$ & $56.13 \mathrm{Aa}$ \\
\hline Derosal Plus ${ }^{\circledast}(\mathrm{F})$ & $51.53 \mathrm{Aa}$ & $56.53 \mathrm{Aa}$ \\
\hline $\operatorname{Maxim} X I^{\circledast}(F)$ & $60.13 \mathrm{Aa}$ & $60.53 \mathrm{Aa}$ \\
\hline Certeza $^{\circledR}(\mathrm{F})$ & $57.00 \mathrm{Aa}$ & 47.97 Aa \\
\hline Standak Top ${ }^{\circledR}$ (IF) & $55.87 \mathrm{Aa}$ & $57.56 \mathrm{Aa}$ \\
\hline Control & $44.33 \mathrm{Bb}$ & $60.53 \mathrm{Aa}$ \\
\hline
\end{tabular}

CV (\%)

14.26

*I: insecticide, F: fungicide. CV: coefficient of variation. Mean values followed by the same lowercase letters in the column and uppercase letters in the row do not differ from each other by the Scott-Knott test at $5 \%$ probability.

Early = treatment performed 60 days before sowing; At sowing = treatment performed moments before sowing. 
application of water. With treatment at the time of sowing, no negative effect of any of the products used was detected on the number of pods parameter, which is an important yield component (Table 8).

The seed treatments did not significantly affect final yield, regardless of the time the treatments were carried out, and the overall mean was $4.416 \mathrm{~kg} . \mathrm{ha}^{-1}$. The mean yield found in this study was higher than the mean in Brazil; according to CONAB (2020), the estimated yield for the 2019/20 crop season was 3,379 kg.ha ${ }^{-1}$, and in the 2018/19 crop season, this value was $3,337 \mathrm{~kg} \cdot \mathrm{ha}^{-1}$.

Final yield in the field did not change from difference in the time of seed treatment, and this allows early application of the treatment at 60 days before sowing, an important result for logistical gains; in addition, it shows the importance of a suitable soybean stand to achieve high yields. Nevertheless, it is necessary to have high quality seeds so that the differences of vigor in initial development caused by seed treatment, above all with insecticides, is compensated over the crop cycle and high yield levels are obtained.

\section{CONCLUSIONS}

Early seed treatment in soybean (at 60 days before sowing) can affect initial development of the plants, but it does not hurt yield.

The phytotoxicity caused by soybean seed treatment, above all with insecticides, is clear from the root length characteristic, analyzed by digital image processing of seedlings. This variable must be considered in quality control.

\section{ACKNOWLEDGMENTS}

Our thanks to FAPEMIG (Fundação de Amparo à Pesquisa do Estado de Minas Gerais), to CAPES (Coordenação de Aperfeiçoamento de Pessoal de Nível Superior), and to the CNPq (Conselho Nacional de Desenvolvimento Cientifico e Tecnológico) for financial support and scholarships. This study was funded in part by the project FAPEMIG - Funding Code CAG - APQ-01869-18.

\section{REFERENCES}

ABUD, H.F.; CICERO, S.M.; GOMES-JUNIOR, F.G. Computerized image analysis of seedlings to evaluate broccoli seed vigor. Journal of Seed Science, v.39, n.3, p.303-310, 2017. http://dx.doi.org/10.1590/2317-1545v39n3174582

BRASIL. Ministério da Agricultura, Pecuária e Abastecimento. Instrução Normativa $\mathrm{n}^{\circ} 45$, de 17 de setembro de 2013 . Diário Oficial da União, seção 1: 45, 25, 20. https://apps.agr.br/instrucao-normativa-no-45-de-17-de-setembro-de-2013/

BRASIL. Ministério da Agricultura, Pecuária e Abastecimento. Regras para Análise de Sementes. Ministério da Agricultura, Pecuária e Abastecimento. Secretaria de Defesa Agropecuária. Brasília, DF: MAPA/ACS, 2009. 395p. https://www.gov.br/agricultura/pt-br/ assuntos/insumos-agropecuarios/arquivos-publicacoes-insumos/2946_regras_analise_sementes.pdf

BRZEZINSKI, C.R.; HENNING, A.A.; ABATI, J.; HENNING, F.A.; FRANÇA-NETO, J.B.; KRZYZANOWSKI, F.C.; ZUCARELI, C. Seeds treatment times in the establishment and yield performance of soybean crops. Journal of Seed Science, v.37, n.2, p.147-153, 2015. https://doi. org/10.1590/2317-1545v37n2148363

CONAB. Companhia Nacional de Abastecimento. Acompanhamento da safra brasileira de grãos 2019/2020: décimo segundo levantamento. https://www.conab.gov.br/info-agro/safras/graos/boletim-da-safra-de-graos. 2020.

CORRÊA, P.D.; CICERO, S.M.; ABUD, H.F. Evaluation cottonseed vigor through computer image analysis of the seedlings. Journal of Seed Science, v.41, n.1, p.54-59, 2019. https://doi.org/10.1590/2317-1545v41n1200649

CHRISTIANSEN, J.E. Irrigation by sprinkling. University of California, Berkeley, California, USA (California Agricultural Experimental Station Bulletin 670), 1942. 
DAN, L.G.M.; DAN, H.A.; BARROSO, A.L.L.; BRACCINI, A.L. Qualidade fisiológica de sementes de soja tratadas com inseticidas sob efeito do armazenamento. Revista Brasileira de Sementes, v.32, n.2, p.131-139, 2010. https://doi.org/10.1590/S010131222010000200016

FERREIRA, D.F. Sisvar: a Guide for its Bootstrap procedures in multiple comparisons. Ciência e Agrotecnologia, v.38, n.2, 2014. http://dx.doi.org/10.1590/S1413-70542014000200001

FERREIRA, T.F.; OLIVEIRA, J.A.; CARVALHO, R.A.D.; RESENDE, L.S.; LOPES, C.G.M.; FERREIRA, V.D.F. Quality of soybean seeds treated with fungicides and insecticides before and after storage. Journal of Seed Science, v.38, n.4, p.278-286, 2016. https://doi. org/10.1590/2317-1545v38n4161760

KRZYZANOWSKI, F. C. Teste de comprimento de raiz de plântula de soja. Informativo ABRATES, Brasília, v.2, n.1, p.11-14, 1991.

LEÃO-ARAÚJO, E.F.; FARIA, J.; BARBOZA, C.; MARCOS-FILHO, J.; VIEIRA, R.D. Controlled deterioration test and use of the Seed Vigor Imaging System (SVIS ${ }^{\circledR}$ ) to evaluate the physiological potential of crambe seeds. Journal of Seed Science, v.39, n.4, p.393-400, 2017. https://doi.org/http://dx.doi.org/10.1590/2317-1545v39n4177911

LUDWIG, M.P.; LUCCA-FILHO, O.A.; BAUDET, L.; DUTRA, L.M.C.; AVELAR, S.A.G.; CRIZEL, R.L. Qualidade de sementes de soja armazenadas após recobrimento com aminoácido, polímero, fungicida e inseticida. Revista Brasileira de Sementes, v.33, n.3, p.395406, 2011. https://doi.org/10.1590/S0101-31222011000300002

MARCOS-FILHO, J. Teste de Envelhecimento Acelerado. In.: KRYZANOWSKI, F.C.; VIEIRA, R. D.; FRANÇA-NETO, J.B. (Eds.) Vigor de sementes: conceitos e testes. Londrina: ABRATES, 1999. p.31-34.

MARCOS-FILHO, J.; KIKUTI, A.L.P.; LIMA, L.B.D. Métodos para avaliação do vigor de sementes de soja, incluindo a análise computadorizada de imagens. Revista Brasileira de Sementes, v.31, n.1, p.102-112, 2009. https://doi.org/10.1590/S010131222009000100012

MARCOS-FILHO, J. Fisiologia de sementes de plantas cultivadas. Londrina: ABRATES, 2015. 660p.

MEDEIROS, A.D.; SILVA, L.J.; CAPOBIANGO, N.P.; FIALHO, C.A.; DIAS, D.C.F.S. Assessing the physiological quality of common bean seeds using the Vigor-S ${ }^{\circledR}$ system and its relation to the accelerated aging test. Journal of Seed Science, v.41, n.2, p.187-195, 2019. https://doi.org/10.1590/2317-1545v41n2211401

NAKAGAWA, J. Testes de vigor baseados na avaliação de plântulas. In: KRZYZANOWSKI, F. C.; VIEIRA, R. D.; FRANÇA-NETO, J. B. (Eds.). Vigor de sementes: conceitos e testes. Londrina: ABRATES, 1999. p.21- 24.

NUNES, R.T.C.; UBIRATAN, O.S.; OTONIEL, M.M.; CAÍQUE, M.S.L. Análise de imagens na avaliação da qualidade fisiológica de sementes. Revista Verde de Agroecologia e Desenvolvimento Sustentável, v.9, n.5, p.84-90, 2014. https://www.gvaa.com.br/ revista/index.php/RVADS/article/view/3339

PEREIRA, L.C.; GARCIA, M.M.; BRACCINI, A.L.; FERRI, G.C.; SUZUKAWA, A.K.; MARTELI, D.C.V.; CORREIA, L.V. Physiological potential of soybean seeds over storage after industrial treatment. Journal of Seed Science, v.40, n.3, p.272-280, 2018. https://doi. org/10.1590/2317-1545v40n3185104

PICCININ, G.G.; BRACCINI, A.L.; DAN, L.G.M.; BAZO, G.L.; LIMA, L.H.S. Influência do armazenamento na qualidade fisiológica de sementes de soja tratadas com inseticidas. Ambiência, v.9, n.2, p.289-298, 2013. https://doi.org/10.5777/ambiencia.2013.02.04

RIBEIRO, A.C.; GUIMARÃES, P.T.G.; ALVAREZ, V.H. Recomendação para o uso de corretivos e fertilizantes em Minas Gerais. Viçosa, MG, CFSEMG/UFV, 1999. 359p.

ROCHA, D.K.; CARVALHO, E.R.; PIRES, R.M.O.; SANTOS, H.O.; PENIDO, A.C.; ANDRADE, D.B. Does the substrate affect the germination of soybean seeds treated with phytosanitary products? Ciência e Agrotecnologia, v. 44, e020119, 2020. http://dx.doi. org/10.1590/1413-7054202044020119

SANTOS, S.F.; CARVALHO, S.F.; ROCHA, D.K.; NASCIMENTO, R.M. Composition and volumes of slurry in soybean seeds treatment in the industry and physiological quality during storage. Journal of Seed Science, v.40, n.1, p.67-74, 2018. https://doi.org/10.1590/23171545v40n1185370

SAKO, Y.; McDONALD, M.B.; FUJIMURA, K.; EVANS, A.F.; BENNETT, M.A. A system for automated seed vigour assessment. Seed Science and Technology, v. 29, n.3 p. 625-636. 2001. 
SILVA, C.B.D.; LOPES, M.D.M.; MARCOS-FILHO, J.; VIEIRA, R.D. Automated system of seedling image analysis (SVIS) and electrical conductivity to assess sun hemp seed vigor. Revista Brasileira de Sementes, v.34, n.1, p.55-60, 2012. https://doi.org/10.1590/ S0101-31222012000100007

STRIEDER, G.; FOGUESATTO, R.J.; GADOTTI, G.I.; LUZ, M.L.G.S.; LUZ, C.A.S.; GOMES, M.C.; SCHERER, V.S. Estudo técnico e de cenários econômicos para implantação de uma unidade de tratamento industrial de sementes de soja e trigo. Informativo Abrates, v.24, n.3, p.118-123, 2014.

VANZOLINI, S.; ARAKI, C.A.S.; SILVA, A.C.T.M.; NAKAGAWA, J. Teste de comprimento de plântula na avaliação da qualidade fisiológica de sementes de soja. Revista Brasileira de Sementes, v.29, n.2, p.90-96, 2007. http://www.scielo.br/pdf/rbs/v29n2/v29n2a12.pdf

VANZOLINI, S.; CARVALHO, N.M. Efeito do vigor de sementes de soja sobre o seu desempenho em campo. Revista Brasileira de Sementes, v.24, n.1, p.33-41, 2002. https://www.scielo.br/scielo.php?script=sci_arttext\&pid=S0101-31222002000100006

WENDT, L.; MALAVASI, M.M.; DRANSKI, J.A.L.; MALAVASI, U.C.; GOMES-JUNIOR, F.G. Relação entre testes de vigor com a emergência a campo em sementes de soja. Revista Brasileira de Ciências Agrárias, v.12, n.1, p.166-171, 2017. https://doi.org/10.5039/agraria. v12i2a5435

ZAMBON, S. Aspectos importantes do Tratamento de Sementes. Informativo ABRATES, v.23, n.2, p.26, 2013. use, distribution, and reproduction in any medium, provided the original work is properly cited. 